\title{
A concise historical perspective of the area postrema structure and function
}

\author{
Uma perspectiva histórica concisa da estrutura e função da área postrema
}

Thiago Ferreira Simões DE SOUZA

\begin{abstract}
First described by Retzius at the end of the 19th century, the structure in the posterior medulla oblongata, then named area postrema, underwent an intense investigation into its function in the decades that followed. Findings, mainly in animal studies, have partially elucidated its role as an emetic center in the central nervous system. In the second half of the 20th century, this function was associated with reports of syndromes characterized by uncontrollable nausea and vomiting related to structural damage in the area postrema, mainly in the context of demyelinating diseases. At the beginning of the $21 \mathrm{st}$ century, the so-called area postrema syndrome has been consolidated as a diagnostic factor in diseases related to the spectrum of neuromyelitis optica, more than 100 years after its first description.
\end{abstract}

Keywords: Area postrema; nausea; vomiting; history of medicine; neuromyelitis optica.

\section{RESUMO}

Descrita pela primeira vez por Retzius no final do século XIX, a estrutura na medula oblonga posterior, então nomeada de área postrema, passou por intensa investigação quanto à sua função nas décadas seguintes. Achados sobretudo em estudos com animais elucidaram parcialmente sua função como centro emético no sistema nervoso central. Na segunda metade do século XX, tal função foi associada a relatos de síndromes caracterizadas por náuseas e vômitos incoercíveis relacionadas a lesões estruturais na área postrema, principalmente no contexto das doenças desmielinizantes. Já no início do século XXI, a então chamada síndrome da área postrema se consolida como fator diagnóstico nas doenças relacionadas ao espectro da neuromielite óptica, mais de 100 anos sua primeira descrição.

Palavras-chave: Área postrema; náusea; vômito; história da medicina; neuromielite óptica.

In the second half of the 19th century, several researchers devoted themselves to shed light on the vomiting reflex by searching for clues that appeared in the new anatomical descriptions of the human brain. In 1865, Gianuzzi speculated on the possible existence of a regulating center of the emetic reflex located in the brain ${ }^{1}$. Thumas, in 1881, pointed to an area on the floor of the fourth ventricle in animals which, if damaged, made apomorphine's emetic action impossible ${ }^{2}$.

In 1896, Magnus Gustaf Retzius (Figure 1), a Swedish neuroanatomist who had already made outstanding contributions to the histology of the nervous system, published a two-volume monograph on the anatomy of the brain, Das Menschenhirn. Studien in der Makroskopischen Morphologie (The Human Brain. Studies in Macroscopic Morphology) ${ }^{3}$. Retzius had, perhaps, produced the most important work on the macroscopic anatomy of the encephalon in the 19th century ${ }^{3}$. In it, for the first time, a structure was described on the floor of the fourth ventricle, adjacent to the nucleus of the solitary tract, named by him as the area postrema (AP), in a free translation from Latin, the hindmost area. The Swedish researcher had produced an extensive work on the anatomy of the sensory organs and nervous system and was nominated for the Nobel Prize in Medicine and Physiology amazingly for 12 times (never having won), but he did not speculate about the likely role of the $\mathrm{AP}^{3,4}$.

After the description by Retzius, Wilson in 1906, in a descriptive work on the human bulb, mentioned the AP as being richly vascularized, as well as detailing histological aspects and pointing out the high density of neurons in that structure $^{5}$. Following his observations, he made notes on the marked delimitation of the AP in relation to the neighboring anatomical structures, thus proposing the substitution of Retzius' nomenclature for nucleus postremus, but did not get the support of his peers. In 1924, Wislocki and Putnam speculated about the postrema region as an area of diffusion between blood and cerebrospinal fluid, after observing dye granules deposited in the perivascular space, especially among ependymal cells ${ }^{6}$.

${ }^{1}$ Hospital da Cruz Vermelha Brasileira, Curitiba-PR, Brasil.

Thiago Ferreira Simões De Souza (iD) https://orcid.org/0000-0002-3695-5752

Correspondence: Thiago Ferreira Simões De Souza; Departamento de Neurologia; Av. Vicente Machado, 1310; 80420-011, Curitiba PR, Brasil; E-mail: thiago. fsimoes@gmail.com

Conflict of interest: There is no conflict of interest to declare.

Received 13 December 2018; Received in final form 14 March 2019; Accepted 05 May 2019. 


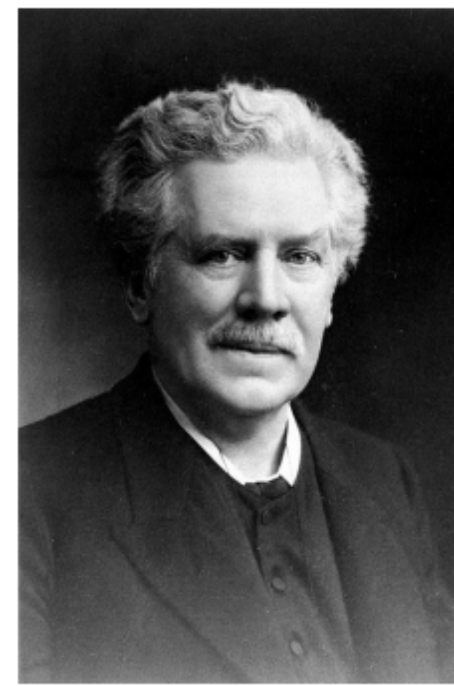

Figure 1. Magnus Gustav Retzius. Photograph by Elliott \& Fry, 1908. Credit: Wellcome Collection. Creative Commons License.

In the 1940s, the knowledge accumulated on the morphology and histology of AP, considered similar to that of the diencephalon nuclei, suggested a neurosecretory function of their cells ${ }^{7}$. In 1951, Borison and Brizzee integrated the hypotheses raised by researchers of the late nineteenth century and, studying the medulla oblongata of cats, identified the AP as a chemoreceptor zone sensitive to the vomiting reflex ${ }^{8}$. More than 20 years later, in 1974, Borison published a review article condensing the advances made by countless other researchers since the early 1950s, concluding that the AP acted primarily as a chemoreceptor trigger zone to the emetic response, knowledge that was already well established at the time9. Despite this, several other studies focused on the AP and sleep regulation, blood pressure, satiety, respiration, renal and choroid plexus function ${ }^{10}$.

Over the next three decades, until the mid-1980s, several authors were divided in the comparative study of the AP in many animal species, but without significant advances in its function. In 1986, already the era of scanning electron microscopy and immunocytochemistry, Leslie published a meticulous comparative study between several animal species and humans. In this article, he detailed the microscopic ultrastructure of the AP, and demonstrated that it was an area of permeability of the blood-brain barrier serving as a zone of fine control of autonomic and neurochemical information. However, the most robust relationship established was still between the AP and the phenomena of nausea and emetic response $^{10}$.

It is interesting to note that even before Retzius' first description and all the growing evidence for AP's function, in 1889, Clarke described a case of an 8-year-old boy with uncontrollable hiccups and vomiting. The outcome of the case was the death of the patient, and a tumor in the middle of the fourth ventricle was found at the postmortem examination, leaving the author curious about the absence of manifestations other than vomiting ${ }^{11}$. More than 50 years later, in 1942, Dow and Berglund, in an article on the vascular patterns of multiple sclerosis lesions, also described the case of a 38-year-old woman with some of the symptoms involving incessant vomiting, and showing postmortem plaques on the pons and medulla oblongata ${ }^{12}$.

After that, countless other reports associated hiccups, nausea, and vomiting, often unrelenting, with lesions in the setting of demyelinating diseases. Although they did not mention a probable involvement of the AP, McFarling and Susac ${ }^{13}$, in 1979, reported on patients with multiple sclerosis with intractable hiccups, a symptom hitherto not reported within their clinical manifestations, relating to probable disinhibition of the hiccup reflex by the multiple sclerosis plaques.

Evidence has been added to a syndromic scenario in action. Although it is difficult to establish when the term "area postrema syndrome" was initially used, in 1984, Borison ${ }^{14}$ mentioned that the activation of AP included a syndrome of nausea and vomiting.

In the 2000s, a profusion of papers correlated area postrema syndrome cases to what has been called neuromyelitis optica spectrum disorders, with AP in a central role as the target of anti-aquaporin 4 antibodies ${ }^{15,16,17,18}$. The syndromic findings in combination with the detailed observations in MRI (Figure 2) and evidence of autoimmunity in action in the AP led to the inclusion of area postrema syndrome in the diagnostic criteria of neuromyelitis optica spectrum disorders in $2015^{19}$. One hundred and nineteen years have passed since the Retzius' first description.

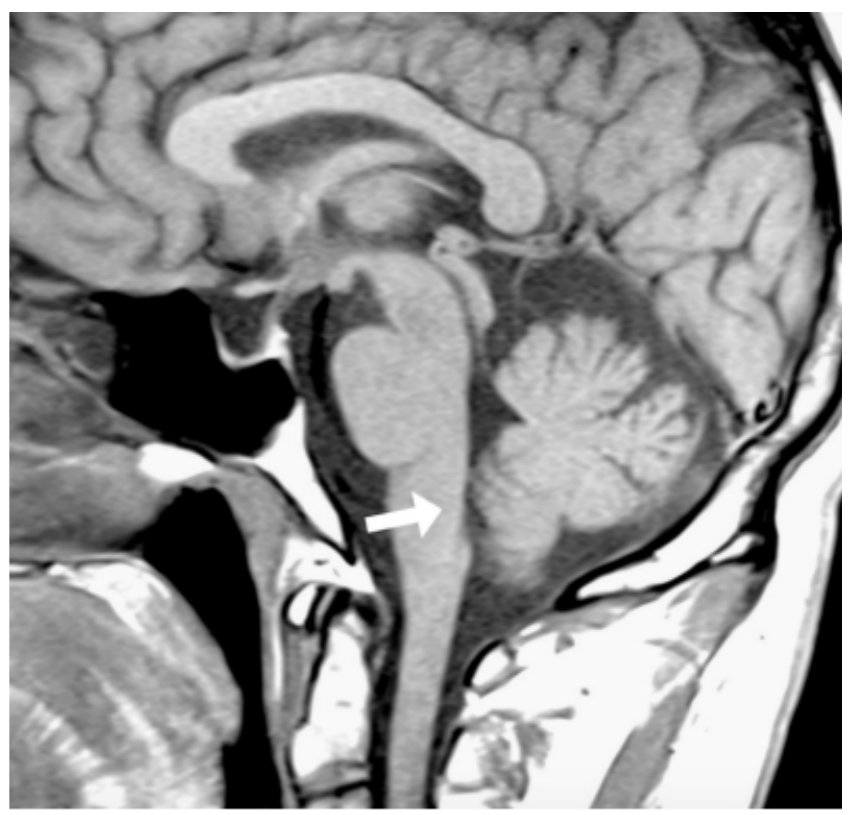

Figure 2. Sagittal T1-weighted MRI sequence showing the approximate location of the area postrema (arrow) on the dorsal inferior surface of the medulla oblongata at the caudal end of the fourth ventricle, a target for anti-aquaporin 4 antibodies in neuromyelitis optica spectrum disorders. 


\section{References}

1. Giannuzzi G. Untersuchungen über die Organe welche an dem Brechact theilnehmen und über die physiologische Wirkung des Tartarus stibiatus. Zentr Med Wiis.1865;3:1.

2. Thumas LJ. Ueber das Brechcentrum und über die Wirkung einige pharmakologischer Mittel auf dasselbe. Arch F Path Anat U Physiol. 1891;123(1):44-69. https://doi.org/10.1007/BF01881928

3. Sarikcioglu L, Yildirim FB. Area postrema: one of the terms described by Magnus Gustaf Retzius. J Hist Neurosci. 2008;17(1):109-10. https://doi.org/10.1080/09647040701236578

4. Grant G. [The histologist and anatomist Gustaf Retzius. He never received the Nobel Prize in spite of his twelve nominations]. Lakartidningen. 2000 Jan;97(1-2):64-70. Swedish.

5. Wilson JT. On the anatomy on the calamus region in the human bulb; with an account of a hitherto undescribed "nucleus postremus.": part II. J Anat Physiol. 1906 Jul;40(Pt 4):357-86.

6. Wislocki GB, Putnam TJ. Further observations on the anatomy and physiology of the areae postremae. Anat Rec. 1924;27(3):151-6. https://doi.org/10.1002/ar.1090270302

7. Cammermeyer J. Is the human area postrema a neuro-vegetative nucleus? Acta Anat (Basel). 1946-1947;2(3-4):294-320. https://doi.org/10.1159/000140216

8. Borison HL, Brizzee KR. Morphology of emetic chemoreceptor trigger zone in cat medulla oblongata. Proc Soc Exp Biol Med. 1951 May;77(1):38-42. https://doi.org/10.3181/00379727-77-18670

9. Borison HL. Area postrema: chemoreceptor trigger zone for vomiting: is that all? Life Sci. 1974 May;14(10):1807-17. https://doi.org/10.1016/0024-3205(74)90399-3

10. Leslie RA. Comparative aspects of the area postrema: fine-structural considerations help to determine its function. Cell Mol Neurobiol. 1986 Jun;6(2):95-120. https://doi.org/10.1007/BF00711065
11. Clarke JM. Tubercle of medulla oblongata. Bristol Med Chir J (1883). 1889; 7(25):194-197.

12. Dow RS, Berglund G. Vascular pattern of lesions of multiple sclerosis. Arch NeurPsych. 1942;47(1):1-18. https://doi.org/10.1001/archneurpsyc.1942.02290010011001

13. McFarling DA, Susac JO. Hoquet diabolique: intractable hiccups as a manifestation of multiple sclerosis. Neurology. 1979 Jun;29(6):797-801. https://doi.org/10.1212/WNL.29.6.797

14. Borison HL. History and status of the area postrema. Fed Proc. 1984 Dec;43(15):2937-40.

15. Misu T, Fujihara K, Nakashima I, Miyazawa I, Okita N, Takase S, et al. Pure optic-spinal form of multiple sclerosis in Japan. Brain. 2002 Nov;125(Pt 11):2460-8. https://doi.org/10.1093/brain/awf260

16. Misu T, Fujihara K, Nakashima I, Sato S, Itoyama Y. Intractable hiccup and nausea with periaqueductal lesions in neuromyelitis optica. Neurology. 2005 Nov;65(9):1479-82. https://doi.org/10.1212/01.wnl.0000183151.19351.82

17. Popescu BF, Lennon VA, Parisi JE, Howe CL, Weigand SD, Cabrera-Gómez JA, et al. Neuromyelitis optica unique area postrema lesions: nausea, vomiting, and pathogenic implications. Neurology. 2011 Apr;76(14):1229-37. https://doi.org/10.1212/WNL.0b013e318214332c

18. Iorio R, Lucchinetti CF, Lennon VA, Farrugia G, Pasricha PJ, Weinshenker BG, et al. Intractable nausea and vomiting from autoantibodies against a brain water channel. Clin Gastroenterol Hepatol. 2013 Mar;11(3):240-5. https://doi.org/10.1016/j.cgh.2012.11.021

19. Wingerchuk DM, Banwell B, Bennett JL, Cabre P, Carroll W, Chitnis T, et al. International consensus diagnostic criteria for neuromyelitis optica spectrum disorders. Neurology. 2015 Jul;85(2):177-89. https://doi.org/10.1212/WNL.0000000000001729 